DOI 10.15290/cnisk.2019.01.06.07

DR ANNA SZWED-WALCZAK

https://orcid.org/0000-0002-9878-1401

Uniwersytet Marii Curie-Skłodowskiej w Lublinie

\title{
Obraz wyborów kontraktowych w Polsce na łamach prasy dla kobiet
}

\begin{abstract}
Streszczenie
4 czerwca 2019 r. minęła 30. rocznica wyborów kontraktowych w Polsce. Dla jednych stanowiła ona symbol zwycięstwa demokracji, dla innych była plebiscytem. Wybory będące konsekwencją porozumień przy Okragłym Stole były z niepokojem oczekiwane zarówno przez stronę rządzą-

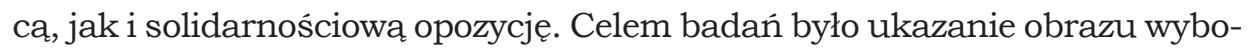
rów kontraktowych w Polsce na łamach prasy dla kobiet. Cezura badawcza objęła okres od rozpoczęcia obrad Okragłego Stołu (luty 1989 r.) do końca lipca 1989 r. W toku badań postawiono pytania badawcze: 1) czy prasa dla kobiet prognozowała przemiany ustrojowe i jak odnosiła się do obrad Okragłego Stołu, 2) w jakim wymiarze (społecznym, politycznym, gospodarczym) w czasopiśmie podejmowano watek wyborów czerwcowych, 3) czy propagowano czytelnikom kandydatów na posłów i senatorów, a jeśli tak, to w jakiej formie (reklama, artykuł sponsorowany, wywiad), 4) jak na łamach prasy oceniano przygotowanie i przebieg wyborów do sejmu i senatu w $1989 \mathrm{r}$.
\end{abstract}

Słowa kluczowe: wybory kontraktowe, obraz wyborów, prasa dla kobiet w Polsce, 1989 


\title{
THE IMAGE OF THE 'CONTRACT ELECTIONS' IN POLAND IN THE WOMEN'S PRESS
}

\begin{abstract}
On 4 June 2019, it was the 30th anniversary of the 'contract elections' in Poland. For some, it was a symbol of the victory of democracy, for others it was a plebiscite. The elections, being a consequence of the agreements of the Polish Round Table Talks, were awaited with concern by both the government and the opposition. The main purpose of this study was to investigate image of the 'contract elections' in Poland in the women's press. The subject of the research were the magazines 'Kobieta i Życie' ['Women and Life'], 'Uroda' ['Beauty'], 'Przyjaciółka' ['Girlfriend'], 'Zwierciadło' ['Mirror'] published after the end of the Round Table Talks until the end of June 1989. In the course of the research, the following questions were posed: 1) Whether the women's press forecasted the political changes and how it referred to the Round Table talks?, 2) In what dimension (social, political, economic) the subject 'contract election' was present in the journal; 3) Whether editorial offices promoted candidates for deputies and senators to readers, if so in what form (advertisement, sponsored articles, interviews); 4) How the preparation and conduct of the Sejm and Senate elections in 1989 were assessed in the women's press?
\end{abstract}

Keywords: 'contract elections', elections' image, women's press in Poland, 1989

\section{Wstęp}

Ocena wyborów kontraktowych w PRL nie jest jednoznaczna. Antoni Dudek nazwał czas przemian transformacyjnych „reglamentowana rewolucja" ${ }^{1}$, Andrzej Paczkowski zaś wybory czerwcowe określił mianem plebiscytu, a ich wynik "momentem "O" " Historycy i politolodzy jednak zgodnie zwracają uwage, że 4 czerwca 1989 r. zakończył „pewna epokę”, a „przypieczętował” go 18 czerwca (druga tura wyborów) ${ }^{3}$. Krystyna

\footnotetext{
1 Antoni Dudek, Reglamentowana rewolucja, (Kraków : Wydawnictwo Znak, 2014).

2 Andrzej Paczkowski, Od sfałszowanego zwycięstwa do prawdziwej klęski. Szkice do portretu PRL, (Kraków : Wydawnictwo Literackie, 1999), 178, 214.

3 Andrzej Małkiewicz, Wybory czerwcowe 1989, (Warszawa : ISP PAN, 1994), 7; Paweł Kowal, Koniec systemu władzy. Polityka ekipy gen. Wojciecha Jaruzelskiego w latach
} 
Trembicka wskazała, że wynik pierwszej tury wyborów zaskoczył zarówno stronę koalicyjno-rządowa, jak i opozycyjną. Dla tej pierwszej klęska wyborcza była szokiem ${ }^{4}$, mimo że zapowiadały ją dostępne dla dygnitarzy partyjnych poufne informacje $z$ przedwyborczych sondaży badania opinii publicznej ${ }^{5}$. Ważny w aspekcie psychologicznym był rezultat wyborów, który pozwolił Komitetowi Obywatelskiemu w pierwszej turze na obsadzenie 160 na 161 możliwych do uzyskania mandatów poselskich, a także 92 senatorskie. Strona koalicyjno-rządowa uzyskała wówczas wyłącznie 3 mandaty do sejmu (które zdobyły osoby powiązane $z$ „Solidarnością” Teresa Liszcz i Władysław Żabiński z ZSL oraz Marian Czerwiński z PZPR, który wkrótce opuścił struktury partyjne) z 299 oraz nie zdobyła żadnego mandatu w wolnych wyborach do senatu. Legitymizacji wyborczej nie uzyskali prominentni działacze, a $z$ listy krajowej mandat otrzymały wyłącznie 2 osoby $^{6}$. Obawy wzbudziły jednak zmiany ordynacji wyborczej wprowadzone dekretem Rady Państwa, zatwierdzone przez sejm 12 czerwca 1989 r. ${ }^{7}$, które pozwoliły na wymianę kandydatów $z$ listy krajowej i wybory uzupełniajace na nieobsadzone mandaty do sejmu ${ }^{8}$.

Zapoczatkowane w drugiej połowie lat 80 . XX w. zarówno zmiany wewnętrzne (m.in. w 1986 r. amnestia dla więźniów politycznych, zaproszenie przedstawicieli środowisk opozycyjnych do Rady Konsultacyjnej przy Przewodniczącym Rady Państwa, na kanwie strajków w 1988 r. prezentacja gotowości władz do rozmów ze stroną opozycyjną, warunko-

\footnotetext{
1986-1989, (Warszawa : Narodowe Centrum Kultury, 2015), 566; Krystyna Trembicka, Okragky stół $w$ Polsce: studium o porozumieniu politycznym, (Lublin : Wydawnictwo UMCS, 2003), 388; Andrzej Friszke, Rok 1989: polska droga do wolności, (Warszawa : Wydawnictwo Sejmowe, 2009), 157; „Kalendarium wyborcze”, w: Polska Wybory '89, układ i wyb. Roman Kałuża, (Warszawa : Wydawnictwo Andrzej Bonarski, 1989), 165.

4 Krystyna Trembicka, Okragły stół $w$ Polsce, 382; Por. Paweł Kowal, Koniec systemu władzy, 563-566.

5 W sondażu opinii z 2 i 3.05.1989 r. poparcie dla opozycji zadeklarowało 45\% respondentów, dla koalicji rządowej $25 \%$, z kolei $20 \%$ pozostawało niezdecydowanych. Dwa tygodnie później poparcie dla opozycji wzrosło do 57\%, nastapił też spadek poparcia dla koalicji rządowej do 23\%, zob. szerzej: Państwowa Jednostka Organizacyjna „Polskie Radio i Telewizja", Ośrodek Badania Opinii Publicznej [dalej: OBOP], Informacja $z$ badań przedwyborczych, PF 2/89, V 1989, 1; OBOP, Informacja $z$ badan przedwyborczych (trzy tygodnie przed wyborami), $\mathrm{PF} 3 / 89,19.05 .1989,1$.

6 A. Friszke, Rok 1989, 55-56.

7 Jak zauważył Andrzej Paczkowski, na posiedzeniu Sekretariatu KC PZPR 5.06.1989 r. nie rozważano możliwości unieważnienia wyników wyborów, lecz postulowano uspokojenie sytuacji wewnętrznej w partii i porozumienie się z „Solidarnościa”, zob. szerzej: Idem, Od sfałszowanego zwycięstwa, 178.

8 „Kalendarium wyborcze”, 54.
} 
wa ${ }^{9}$ propozycja legalizacji „Solidarności”) ${ }^{10}$, jak i zewnętrzne (np. reformy polityczne Michaiła Gorbaczowa, upadek gospodarki socjalistycznej) rozbudziły nadzieje społeczne. Oczekiwania wzrastały, choćby z powodu pokojowego nastawienia stron konfliktu, czego egzemplifikacja były obrady Okragłego Stołu ${ }^{11}$. Taka forma renegocjacji systemu politycznego sprzyjała obu stronom - partyjna chroniła od gniewu społecznego, opozycyjna przed rewolucja. Transformacja ustrojowa stanowiła więc szansę na zmianę nie tylko ustroju politycznego i gospodarczego, lecz także na zamanifestowanie obecności konkretnych grup społecznych, zabezpieczenia ich interesów i praw.

Celem badań było ukazanie obrazu wyborów kontraktowych w Polsce na łamach prasy dla kobiet, często definiowanej poprzez pryzmat funkcji poradnikowej, pozwalającej na rozwiąywanie trudów życia codziennego ${ }^{12}$. Warto powołać się na stanowisko Zofii Lewartowskiej, która stwierdziła, że ten rodzaj prasy szczególnie rozwijał się w okresach przemian politycznych i rewolucyjnych ${ }^{13}$, co jest zgodne $z$ postawiona teza, iż redakcje prasy dla kobiet przed wyborami kontraktowymi zwracały uwage na kwestie zwiazane $z$ docenieniem roli i znaczenia kobiet w polityce oraz możliwości ich realnego wpływu na poprawę sytuacji gospodarstw domowych. Ważne było więc zweryfikowanie: 1) czy prasa dla

9 Legalizacja „Solidarności” miała nastapić, jeśli jej przedstawiciele zgodzą się na wybory, w których będą mogli uzyskać określoną w kontrakcie reprezentację, za to władza wyraziła zgodę na wolne wybory do senatu, w zamian oczekując kompromisu w postaci partyjnego prezydenta; Andrzej Małkiewicz, Wybory czerwcowe 1989, 13.

10 Ibidem, 11-13.

11 Wyniki sondażu przeprowadzonego przez OBOP w lutym 1989 r. na próbie (370) warszawiaków wykazały, że respondenci byli przekonani, iż obrady Okragłego Stołu doprowadzą do porozumienia w sprawach: legalizacji „Solidarności”, zmiany ordynacji wyborczej i reform gospodarczych. Z kolei w kwietniu (próba 200 warszawiaków) zwrócono uwagę, że porozumienie nie wpłynie na poprawę gospodarki, ale doprowadzi do demokratyzacji życia i redukcji konfliktów społecznych, zob.: OBOP, Komunikat $z$ badań: Inauguracja obrad Okragłego Stołu w opinii mieszkańców Warszawy, nr 4/506, 7.02.1989, 2; OBOP, Komunikat z badañ: Opinie mieszkańców Warszawy o obradach Okragłego Stołu, nr 14/516, 7.04.1989, 1. Warto odnieść się też do wyników sondażu na temat nastrojów społecznych, w którym odnotowano wzrost przekonania o poprawie sytuacji w kraju z 6\% w marcu do $27 \%$ w maju. Respondenci ocenili również nastroje społeczne jako dobre i bardzo dobre w 36\% (wzrost od marca o 18\%), jako niedobre lub złe w 50\% (spadek od marca o 24\%), zob. OBOP, Komunikat z badań: Nastroje społeczne w maju 1989 r., nr 20/520, maj 1989, 1.

12 Zofia Sokól, „Redaktorzy naczelni czasopism kobiecych w Polsce w latach 1944-1982 (portret zbiorowy)", Kwartalnik Historii Prasy Polskiej, t. 30, nr 1, 1991, 87.

13 Zob. szerzej: Zofia Lewartowska, „Prasa kobieca i rodzinna”, Zeszyty Prasoznawcze, $\mathrm{nr}$ 4, 1975, 67. 
kobiet prognozowała przemiany ustrojowe oraz jak odnosiła się do obrad Okragłego Stołu, 2) w jakim wymiarze (społecznym, politycznym, gospodarczym) w czasopismach podejmowano wątek wyborów czerwcowych, 3) czy propagowano czytelnikom kandydatów na posłów i senatorów, jeśli tak, to w jakiej formie (reklama, artykuł sponsorowany, wywiad), 4) jak na łamach prasy oceniano przygotowanie i przebieg wyborów do sejmu i senatu w 1989 r.

Cezura początkowa był luty 1989 r. (podyktowane było to potrzeba zweryfikowania czy pojawily się prognozy o nadchodzacych zmianach w zwiazku z rozpoczęciem 6 lutego obrad Okragłego Stołu), końcową zaś lipiec 1989 r. (kiedy to odbyło się pierwsze posiedzenie Sejmu X kadencji, nastapił wybór gen. Wojciecha Jaruzelskiego na prezydenta przez Zgromadzenie Narodowe ${ }^{14}$, a na łamach czasopism czyniono powyborcze refleksje).

Przedmiotem badań były czasopisma dla kobiet o ugruntowanej pozycji rynkowej. W 1989 r. funkcjonowało ich szesnaście. W IV kwartale 1989 r. ich średni nakład (w tys.) wynosił: tygodnik „Przyjaciółka”: 1.908,7 (Wydawnictwo Współczesne, dalej: WW), tygodnik „Kobieta i Życie”: 696,6 (Warszawskie Wydawnictwo Prasowe, dalej: WWP), „Sezam. Kwartalnik Przyjaciółki”: 500,7 (WW), miesięcznik „Wykroje i Wzory”: 418,2 (WWP), kwartalnik „Pani” (WWP): 310, „Kalendarz Przyjaciółki” (WW): 300, dwutygodnik „Filipinka”: 245 (WWP), dwumiesięcznik w wersji polskiej „Uroda” (Polska Agencja „Interpress”): 231 i niemieckiej, „Mir Mody” (WWP): 201,5, miesięczniki „Ewa. Magazyn Zdrowia i Urody” (WWP): 200,2, „Magazyn Rodzinny” (WWP): 172, Składanka „Świata Mody”: 153,8 (WWP), tygodnik „Zwierciadło” (Oficyna Wydawnicza „Wiedza i Życie”): 132,6, kwartalnik „Swiat Mody” (WWP): 101, miesięcznik Zarządu Głównego Ligi Kobiet „Nasza Praca” (WWP): $2^{15}$. W toku badań zrezygnowano $z$ analizy kwartalnika „Pani” ze względu na to, że jego pierwszy numer pojawił się na jesieni 1989 r., wyeliminowano też wy-

14 Co nastapiło 19.07.1989 r. Jak zauważyła Krystyna Trembicka, wybór ten nastapił przewaga jednego głosu i dzięki „37 głosom przedstawicieli opozycji, którzy wstrzymali się, oddali głosy nieważne bądź nie uczestniczyli w głosowaniu”. Stanowił on także realizację nieformalnych postanowień poczynionych podczas obrad Okragłego Stołu; Krystyna Trembicka, Okragły stół w Polsce, 383-384.

15 Zob. szerzej: Zofia Sokół, „Transformacja czasopism kobiecych w Polsce (1989-1997)”, Rocznik Historii Prasy Polskiej, t. 1, z. 1-2, 1998, 193-201. 
danie rosyjskie czasopisma „Świat Mody”" niemiecka mutację „Urody”, Składankę „Swiata Mody” oraz mającą niewielki nakład „Naszą Pracę”.

Tabela nr 1. Frekwencyjność tematów dotyczących przemian politycznych w Polsce w okresie od 6 lutego do 30 lipca 1989 r.

\begin{tabular}{|c|c|c|c|c|c|c|c|c|c|c|c|}
\hline \multirow[b]{2}{*}{ Tematyka } & \multicolumn{11}{|c|}{ Liczba tematycznych artykułów } \\
\hline & 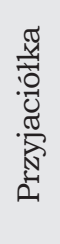 & 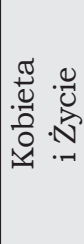 & 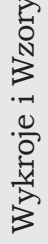 & 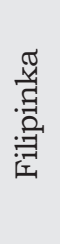 & 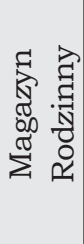 & 茥 & 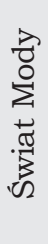 & 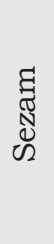 & 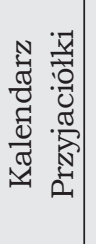 & $\begin{array}{l}\frac{\pi}{8} \\
\frac{0}{5} \\
5\end{array}$ & 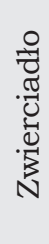 \\
\hline Okrąły Stół & 17 & 4 & 0 & 3 & 0 & 0 & 0 & 0 & 0 & 0 & 7 \\
\hline $\begin{array}{l}\text { Wybory } \\
\text { czerwcowe }\end{array}$ & 15 & 11 & 0 & 3 & 1 & 0 & 0 & 0 & 0 & 0 & 7 \\
\hline $\begin{array}{l}\text { Prawa polityczne } \\
\text { kobiet }\end{array}$ & 5 & 14 & 0 & 2 & 3 & 0 & 0 & 0 & 0 & 1 & 14 \\
\hline Prawa socjalne & 3 & 2 & 0 & 0 & 1 & 0 & 0 & 0 & 0 & 0 & 3 \\
\hline $\begin{array}{l}\text { Problemy } \\
\text { gospodarcze }\end{array}$ & 2 & 8 & 0 & 0 & 2 & 0 & 0 & 0 & 0 & 0 & 0 \\
\hline $\begin{array}{l}\text { Reklama } \\
\text { polityczna }\end{array}$ & 7 & 7 & 0 & 2 & 0 & 0 & 0 & 0 & 0 & 1 & 5 \\
\hline Liczba art. & 49 & 46 & 0 & 10 & 0 & 0 & 0 & 0 & 0 & 2 & 36 \\
\hline $\begin{array}{l}\text { Liczba } \\
\text { przebadanych } \\
\text { numerów }\end{array}$ & 23 & 23 & 6 & 12 & 7 & 3 & 2 & 2 & 1 & 3 & 23 \\
\hline
\end{tabular}

Źródło: opracowanie własne.

Wskazać należy, że badane czasopisma łączyła szeroka klasyfikacja do kategorii prasy dla kobiet, różnicowała je natomiast szczegółowa segmentacja odbiorców. „Kobieta i Życie” przeznaczona była dla wykształconych kobiet z miast, „Przyjaciółka” dla mieszkanek małych miejscowości i wsi, „Zwierciadło” dla inteligentek i kobiet nowoczesnych, „Filipinkę" zainicjowano z myślą o nastolatkach, „Magazyn Rodzinny” miał zaś poszerzyć grono czytelników o dzieci i mężów. W procesie badawczym zastosowano analizę zawartości prasy. Pozwoliła ona na właścisy dobór próby, analize treści pod katem obrazu wyborów fontrak -

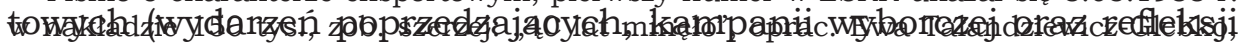
Swiat Mody, nr 160, 1989, 21-22. 
powyborczych) i frekwencyjności badanych treści ${ }^{17}$. Część popularnych pism dla kobiet w ogóle nie poruszała tematów o charakterze politycznym (zob. tabela nr 1).

Dostrzec można, że problematyka ta pojawiała się w tygodnikach „Przyjaciółka”, „Kobieta i Życie”, „Zwierciadło” i dwutygodniku „Filipinka”, sporadycznie w miesięczniku „Magazyn Rodzinny”. Brak popularności tych zagadnień w pozostałych pismach wynikał $z$ ograniczenia ich treści do wątków mody, stylu życia i urody, a redakcje, skupiając się na poradnictwie, rezygnowały $z$ realizacji opiniotwórczej funkcji prasy. Ponadto należy wskazać, że pisma te były związane $z$ tygodnikami, które nie pomijały wątków społecznych i politycznych.

\section{Obrady Okrągłego Stołu w prasie dla kobiet}

Najwięcej materiałów w badanym okresie na temat porozumienia koalicji rządowej z opozycja solidarnościową pojawiło się w „Przyjaciółce” (17) i „Zwierciadle” (7). Obrady Okragłego Stołu zostały ukazane w prasie dla kobiet jako preludium do reform. $Z$ jednej strony wzbudzały nadzieje na rychłe zmiany społeczne, gospodarcze i polityczne w Polsce ${ }^{18}, z$ drugiej zaś pojawiło się rozczarowanie związane $z$ niereprezentatywnością kobiet (na 56 mężczyzn zaproszono jedną kobietę - prof. Annę Przecławska) na inauguracji obrad Okragłego Stołu, $z$ brakiem w głównym dyskursie tematyki dotyczącej choćby warunków pracy kobiet (np. w przemyśle lekkim) czy zespołu ds. kobiet. Na watki te zwracała uwage przede wszystkim redakcja tygodnika „Kobieta i Życie” ${ }^{19}$. Refleksje te skłoniły redakcję do organizacji konkurencyjnego „kobiecego stołu” ${ }^{20}$, którego efekty

17 Zob. szerzej: Walery Pisarek, Wstęp do nauki o komunikowaniu, (Warszawa : Wydawnictwo Akademickie i Profesjonalne, 2008), 248.

18 Co znalazło głównie odzwierciedlenie w listach czytelniczek: „Pisane kobiecą ręką. Listy, które w lutym i marcu br. nadeszły do uczestników Okragłego Stołu czytała i do druku podała Natalia Iwaszkiewicz", Kobieta i Życie [dalej: KiŻ], nr 15, 12.04.1989, 2-3.

19 „O nas bez nas”, oprac. Krystyna Kaszuba, KiŻ, nr 13, 29.03.1989, 4-5; „O nas bez nas” (2), oprac. Krystyna Kaszuba, KiŻ, nr 14, 5.04.1989, 2; „O nas bez nas”, oprac. Krystyna Kaszuba, Ki்̇, nr 45, 22.11.1989, 5.

20 W obradach „kobiecego okragłego stołu” uczestniczyły: dziennikarka Krystyna Kaszuba (ze strony redakcji), pracownicy naukowi: dr Danuta Waniek (Akademia Nauk Społecznych, liderka grupy kobiet w „Ruchu 8 lipca”), doc. Renata Siemieńska i doc. Irena Reszke (Instytut Socjologii i Filozofii UW), Danuta Graniewska (Instytut Pracy i Spraw Socjalnych), przewodnicząca Ligi Kobiet Polskich Elżbieta Lęcznarowicz, Janina Michalska i Helena Zakrzewska z Komisji Kobiet Episkopatu Polski, reżyserka Barbara Sass oraz 
zamieszczano w rubryce "O nas bez nas”. Określenie to zaproponowała jedna $z$ jego uczestniczek - Renata Siemińska, nazywając w ten sposób politykę wobec kobiet ${ }^{21}$.

Obrady Okragłego Stołu w tygodniku „Kobieta i Życie” stały się więc impulsem do redakcyjnej analizy kwestii równouprawnienia płci w zakresie: awansu zawodowego i politycznego (zwracano uwage na brak liderek w stronnictwach politycznych), płac, dostępności do urzędów publicznych, wpływu na funkcjonowanie przemysłu lekkiego, odpowiedzialności za gospodarstwo domowe. Oskarżano polityków o niewykorzystanie potencjału intelektualnego i zawodowego kobiet ze szkodą dla państwa. Podejmowano również wątek wprowadzenia parytetów wyborczych, które mogłyby zachęcić kobiety do aktywności politycznej ${ }^{22}$.

Na łamach „Przyjaciółki” obrady Okragłego Stołu określano jako wydarzenie o „historycznej doniosłości”23, „wielką szansą wybicia się Polski na normalność, na trwały spokój społeczny, na ład ekonomiczny"24. Wskazywano, że pokojowe przemiany ustrojowe wpływają na pozytywny wizerunek Polski jako wiarygodnego partnera dla wspólnoty europejskiej $^{25}$. Z optymizmem podsumowano ich zakończenie: „Mamy już zatem stworzona przez strony reprezentujące większość społeczeństwa, prawie wszystkie jego odłamy, wizje przyszłość Polski - państwa socjalistycznej demokracji parlamentarnej”26. Wyjaśniano wagę reform politycznych dla przyszłości państwa ${ }^{27}$. Redakcja „Przyjaciółki” pozytywnie oceniała porozumienie „okragłostołowe”. Nie podejmowano wątku niewielkiej reprezentacji kobiet.

W tygodniku „Zwierciadło” obrady Okragłego Stołu ukazywano przez pryzmat ważnych dla jego czytelników spraw - przede wszystkim kwestii edukacji, gospodarki, pluralizmu politycznego i rozpoczęcia de-

\footnotetext{
Wanda Żor i Jolanta Owidzka (dyrektor Biura Rzecznika Rządu ds. Kobiet), „O nas bez nas", oprac. Krystyna Kaszuba, KiŻ, nr 13, 29.03.1989, 4-5.

21 Ibidem.

22 Ibidem; „O nas bez nas” (2), oprac. Krystyna Kaszuba, KiŻ, nr 14, 5.04.1989, 3; „Jeśli nie my, to kto?", KiŻ, nr 20, 17.05.1989, 2.

23 Elżbieta Banasiak, „Wiosna w polskim parlamencie”, „Przyjaciółka” [dalej: Prz], nr 13, 30.03.1989, 4.

24 Wiesława Piątek, „Na dobry początek”, Prz, nr 15, 13.04.1989, 4; Eadem, „Nie zmarnujmy szansy", Prz, nr 7, 16.02.1989, 4.

25 Obserwator, „Reflektory na Polske”, Prz, nr 7, 16.02.1989, 4.

26 Wiesława Piątek, „Na dobry początek”, Prz, nr 15, 13.04.1989, 4.

27 Elżbieta Banasiak, „Wiosna w polskim parlamencie”, Prz, nr 13, 30.03.1989, 4.
} 
mokratyzacji życia społecznego ${ }^{28}$. Do prezentacji treści o przygotowaniu, przebiegu, ocenie obrad wykorzystywano różne gatunki dziennikarskie. Już w lutym przeprowadzono wywiad $z$ Arturem Bodnarem, uczestnikiem prac przygotowawczych ${ }^{29}$, publikowano reportaże, w których przedstawiciele oświaty oceniali przebieg rozmów i prezentowali własne oczekiwania wobec reformy systemu edukacji ${ }^{30}$. Warto podkreślić, że na łamach pisma pojawiały się wywiady $z$ przedstawicielami strony koalicyjno-rzadowej oraz opozycyjnej ${ }^{31}$, w których dopytywano o ustalenia Okragłego Stołu, ale też ich recenzje. Prognozowano, czy możliwe będzie szybkie rozwiązanie problemów w edukacji i budownictwie mieszkaniowym ${ }^{32}$.

Podobnie jak w „Przyjaciółce”, również w dwutygodniku „Filipinka” i „Magazynie Rodzinnym” zwracano uwage na pozytywne aspekty obrad Okragłego Stołu ${ }^{33}$. Ze względu na adresatów dwutygodnika „Filipinka” porozumienia oceniano przez pryzmat edukacji oraz spraw młodzieży ${ }^{34}$.

Należy stwierdzić, że w prasie dla kobiet o charakterze opiniotwórczym obserwowano i opisywano wydarzenia polityczne w Polsce, doceniajac ich rolę dla zmiany systemu politycznego. Tematyka ta nie była zaskoczeniem dla czytelniczek „Przyjaciółki”. W tygodniku bowiem funkcjonowały stałe rubryki i działy, w których prezentowano wzmianki i komentarze na temat polityki krajowej i zagranicznej, tj. „Z kraju”35, „Okno na świat”, „Fakty, Ciekawostki i Poglądy”. Można zauważyć otwarcie re-

28 Krystyna Stachowicz, „Czekamy na partnera”, Zwierciadto [dalej: $Z w$ ], nr 17, 27.04.1989, 3; Eadem, „Jedność w różnorodności”, $Z w$, nr 17, 27.04.1989, 4-5; Elżbieta Wierzbicka, „Przedwyborcza ściągawka”, Zw, nr 19, 11.05.1989, 4-5.

29 Wywiad Wiesławy Lipińskiej z prof. Arturem Bodnarem: „Budować od dołu”, $Z w$, nr 6, 9.02.1989, 4.

30 Alina Gutek, „Daleko od stołu”, Zw, nr 14, 6.04.1989, 3; Rozmowa Aliny Gutek z prof. Henrykiem Samsonowiczem, przewodniczacym komisji oświaty i nauki w Komitecie obywatelskim przy Lechu Wałęsie: „Stwórzmy zdrowa szkołę”, Zw, nr 19, 11.05.1989, 2.

31 Rozmowa Elżbiety Wierzbickiej z prof. Jerzym Ciemieniewskim, ekspertem strony opozycyjno-solidarnościowej przy Okragłym Stole: „Stare wątpliwości”, Zw, nr 20, 18.05.1989, 4-5; Rozmowa Elżbiety Wierzbickiej z doc. dr. hab. Stanisławem Gebethnerem: „Ostrożny optymizm”, Zw, nr 20, 18.05.1989, 4-5; Wywiad Barbary Skrzypińskiej z Zofią Kuratowską: „Ochrona zdrowia - sprawa publiczna”, $Z w$, nr 18, 4.05.1989, 3, 8.

32 Alina Gutek, „Daleko od stołu”, $Z w$, nr 14, 6.04.1989, 3; Wiesława Lipińska, „Nowe budownictwo", $Z w, \mathrm{nr}$ 19, 11.05.1989, 6-7.

33 Hanna Jaworska, „Od Redaktora”, Filipinka [dalej: Fil], nr 5, 26.02.1989, 3; Eadem, „Od Redaktora”, Fil, nr 10, 7.05.1989, 3; Bożena Zwolińska-Kańtoch, „Od Redaktora”, Magazyn Rodzinny, nr 182, czerwiec 1989, 45.

34 Hanna Jaworska, „Od Redaktora”, Fil, nr 9, 23.04.1989, 3; Joanna Młynarczyk, „Pochodowe? Alternatywne”, Fil, nr 10, 7.05.1989, 4-5, 13.

35 Elżbieta Banasiak, „Propozycje dla rządu”, Prz, nr 1, 5.01.1989. 
dakcji „Zwierciadła” na stronę opozycyjną, o czym świadczyły wywiady z przedstawicielami „Solidarności”. Dostrzegalne było też, że redakcje oceniały efekty obrad Okragłego Stołu przez pryzmat dominujaccych w ich pismach tematów: walki o równouprawnienie płci w „Kobiecie i Życiu”, edukacji w „Zwierciadle” $i$ „Filipince”, spraw młodzieżowych w „Filipince”. We wskazanych tytułach $z$ uznaniem i zadowoleniem pisano o wdrażaniu zasad pluralizmu politycznego w Polsce.

\section{Wielowymiarowość wyborów czerwcowych}

Kampanię wyborczą w 1989 r. w większości pism dla kobiet zmajoryzowała kwestia projektu ustawy o prawnej ochronie życia poczętego, autorstwa zespołu ekspertów przy Episkopacie. Jej celem było zniesienie Ustawy z dnia 27 kwietnia 1956 r. o warunkach dopuszczalności przerwania ciaży i wprowadzenie bezwzględnego zakazu aborcji. Projekt do Marszałka Sejmu wpłynął 23 lutego 1989 r.

Redakcje prasy dla kobiet oceniały go krytycznie, jednocześnie wskazując też na swój sceptycyzm wobec sztucznego przerywania ciąży ${ }^{36}$. W tygodnikach „Kobieta i Życie”, „Zwierciadło” opublikowano stanowisko Ligi Kobiet Polskich w tej sprawie, gdzie wskazano, że aborcja jest „złem koniecznym” i rozwiazaniem „w przypadkach krańcowych”, zapobiegającym nielegalnym praktykom. Penalizacja aborcji zdaniem LPK pozbawiała kobiety podmiotowości i prawa do decydowania. W zamian radykalizacji prawa proponowano promocję i dostępność antykoncepcji, działania edukacyjne, poprawę opieki zdrowotnej. Apelowano o równość kobiet i mężczyzn wobec prawa, a więc też moralną i prawną współodpowiedzialność za aborcję ${ }^{37}$.

Redakcja „Magazynu Rodzinnego” zwróciła uwagę na „antyhumanitarny" wymiar projektu, narzucajacy innym normy etyczne, przeczacy

\footnotetext{
36 „Chcemy o tym decydować”, $Z w$, nr 16, 20.04.1989, 2; Anna Frankowska, „Protokół rozbieżności”, KiŻ, nr 24, 14.06.1989, 11; „Stanowisko Ligi Kobiet Polskich w sprawie dopuszczalności przerywania ciąży”, $Z w$, nr 18, 4.05.1989, 4-5; Krystyna Kurczab-Redlich, „Sprawa przerywania ciaży: Ostatnia furtka”, Prz, nr 18, 4.05.1989, 6; K. K-R., „Bolesna sprawa", Prz, nr 24, 15.06.1989, 5.

37 „Stanowisko Ligi Kobiet Polskich w sprawie dopuszczalności przerywania ciąży w związku z projektem poselskim ustawy o prawnej ochronie dziecka poczętego", KiŻ, nr 20, 17.05.1989, 11; „Stanowisko Ligi Kobiet Polskich w sprawie dopuszczalności przerywania ciąży", $Z w, \mathrm{nr}$ 18, 4.05.1989, 4.
} 
idei świadomego macierzyństwa ${ }^{38}$. W „Zwierciadle” projekt ustawy oceniono jako „zamach na prawo wyboru, decydowania o sobie i swoim potomstwie”39. Na łamach „Kobiety i Życia” stwierdzono, że propozycja ustawy o ochronie życia poczętego jest przejawem nierówności płci ${ }^{40}$. Przerywanie ciąży określano mianem „mniejszego zła”, gdyż w przypadku represji za zabieg nastapi rozwój „podziemia aborcyjnego"41. Projekt ustawy skłonił też do refleksji o braku wiedzy Polek w zakresie antykoncepcji ${ }^{42}$. Tematyka ta wzbudziła zainteresowanie czytelniczek, które przesyłały do redakcji listy poparcia bądz krytyki propozycji zaostrzenia prawa ${ }^{43}$.

W „Przyjaciółce” zdecydowanie rzadziej podejmowano się oceny projektu ustawy. W piśmie odnotowano warszawską manifestację sprzeciwu wobec projektu oraz zaprezentowano krytyczne wypowiedzi kobiet na temat zmian $\mathrm{w}$ tym zakresie ${ }^{44}$. Szczegółowe rozważania pojawiły się po wyborach ${ }^{45}$. $Z$ kolei w „Filipince” w badanym okresie w ogóle nie poruszano tego watku.

Kolejnym tematem podnoszonym na łamach prasy dla kobiet w czasie kampanii wyborczej była kwestia równouprawnienia płci w zakresie dostępności do decydowania politycznego. Za ważne uznano współrządzenie kobiet i mężczyzn, a przede wszystkim decydowanie kobiet o sprawach dotyczacych ich bezpośrednio ${ }^{46}$. Barbara Sieradzka stwierdziła, że należy zmienić świadomość społeczna, gdyż mocne fundamenty tradycyjnego pojęcia roli matki i żony skutkują brakiem popar-

38 Renata Kopczewska, „Prawo do decyzji”, Magazyn Rodzinny, nr 182, czerwiec 1989, 16-17.

39 "Chcemy o tym decydować”, $Z w$, nr 16, 20.04.1989, 2.

40 Anna Frankowska, „Protokół rozbieżności”, KiŻ, nr 24, 14.06.1989, 11.

41 „Źle strzeżona brama”, Ki்̇, nr 15, 5.04.1989, 5.

42 Zofia Zubczewska, „Mą̇̇ uważa, czyli antykoncepcja po polsku”, KiŻ, nr 17, 26.04.1989, 2-3.

${ }^{43}$ „Zabieg 2”, Kì̇, nr 14, 5.06.1989, 10-11; „Nie ma racji bezwarunkowych”, Magazyn Rodzinny, nr 183, lipiec 1989, 44-45; „Za i przeciw ustawie”, Zw, nr 18, 4.05.1989, 4-5; „Za i przeciw...”, Zw, nr 19, 11.05.1989, 4; „Za i przeciw...”, Zw, nr 20, 18.05.1989, 6; "Chcemy o tym decydować”, $Z w$, nr 21, 25.05.1989, 2-3; „Chcemy o tym decydować”, $Z w$, nr 22, 1.06.1989, 4-5; „Chcemy o tym decydować, $Z w$, nr 24, 15.04.1989, 3.

${ }^{44}$ Krystyna Kurczab-Redlich, „Sprawa przerywania ciaży: ostatnia furtka”, Prz, nr 18, 4.05.1989, 6; K. K-R., „Bolesna sprawa”, Prz, nr 24, 15.06.1989.

45 „To musisz wiedzieć, by mieć własne zdanie”, Prz, nr 27, 6.07.1989, 4.

46 „Jeśli nie my, to kto?”, Ki்̇, nr 20, 17.05.1989; „Blisko życia zwykłych ludzi. «Kobieta i życie" rozmawia z przewodnicząca Ligi Kobiet Polskich Elżbietą Lęcznarowicz rozmawia Alicja Bińska”, Ki̇̇, nr 23, 7.06.1989, 2; Bożena Zwolińska-Kańtoch, „Od Redaktora”, Magazyn Rodzinny, nr 182, czerwiec 1989, 45. 
cia dla reprezentacji politycznej kobiet ${ }^{47}$. Prezentowano więc pozytywne wzorce kobiet, które połączyły karierę zawodową z życiem prywatnym, oraz promowano sylwetki aktywistek społecznych ${ }^{48}$.

Redakcje „Kobiety i Życia”, „Przyjaciółki”, „Zwierciadła”, „Filipinki” realizowały przed wyborami kampanię edukacyjną i profrekwencyjna. Tłumaczono: 1) do jakich instytucji odbywają się wybory i jakie są kompetencje sejmu, senatu, prezydenta, 2) czym jest krajowa lista kandydatów na posłów Sejmu X kadencji, 3) w jaki sposób oddać ważny głos i kiedy głos uznawany jest za nieważny, 4) jakie dokumenty wziąc na głosowanie ${ }^{49}$.

W „Przyjaciółce” apelowano o odpowiedzialny udział w wyborach, wyszczególniono pilne problemy ${ }^{50}$ (dotyczące życia codziennego polskich rodzin, a w szczególności kobiet), które kandydat lub kandydatka powinni uwzględnić w programie wyborczym. Podobnie w „Zwierciadle” i „Magazynie Rodzinnym" ukazywano wagę wyborów czerwcowych, zachęcano do świadomego podejmowania decyzji wyborczej i zalecano, aby zapoznać się z życiorysami kandydatów ${ }^{51}$. Na łamach „Filipinki” i „Przyjaciółki” prezentowano wymagane cechy przyszłego posła i senatora (m.in.: stałe doskonalenie siebie i świata, odróżnianie spraw błahych od ważnych, decyzyjność i konsekwencja w działaniu, mocny kręgosłup moralny, tolerancja, uczciwość, odwaga, odpowiedzialność za słowo, umiejętność współpracy) $)^{52}$. W „Filipince” edukowano czytelniczki, że demokracja wymaga odpowiedzialności, a więc każdy obywatel państwa (nawet jeszcze

47 „Jeśli nie my, to kto?”, Ki்̇, nr 20, 17.05.1989, 3.

48 Joanna Czaj, „Wywiad z Wanda Chrzanowska: Przebudzenie?”, Ki்̇, nr 22, 31.05.1989, 5-6; AMO, „Punktujemy”, Fil, nr 10, 7.05.1989, 2.

49 Fra, „Jak głosujemy?”, Ki்̇, nr 22, 31.05.1989, 11; „Jak wybieramy?”, Prz, nr 22, 1.06.1989, 5; Wiesława Piątek, „By wybierać dobrze”, Prz, nr 18, 4.05.1989, 4; Elżbieta Wierzbicka, „Przedwyborcza ściagaczka”, Zw, nr 19, 11.05.1989, 5; Hanna Jaworska, „Od Redaktora", Fil, nr 11, 21.05.1989, 3.

50 Dotyczyły one działań w służbie zdrowia (braku dostępności leków i sprzętu medycznego, środków opatrunkowych i antykoncepcyjnych), zaopatrzenia w żywność i artykuły przemysłowe, rozwoju budownictwa, instytucji opiekuńczych dla dzieci, kontroli wdrażania reform, nowelizacji prawa w zakresie eksmisji, alimentów, konsultacji społecznych, profitów dla firmy zatrudniających osoby niepełnosprawne; Redakcja, „Przed wyborami do Sejmu i Senatu: przeczytaj - zastanów się - przedstaw swój pogląd", Prz, nr 19, 11.05.1989, 4; Redakcja, „To my możemy wygrać!”, Prz, nr 19, 11.05.1989, 4.

51 Elżbieta Wierzbicka, „Przedwyborcza ściagawka”, $Z w$, nr 19, 11.05.1989, 4-5; Bożena Zwolińska-Kańtoch, „Od Redaktora”, Magazyn Rodzinny, nr 182, czerwiec 1989, 45.

52 Joanna Młynarczyk, „Oczy Pollyanny”, Fil, nr 12, 4.06.1989, 4; „Jacy powinni być posłowie”, wypowiedzi wysłuchała Elżbieta Banasiak, Prz, nr 20, 18.05.1989, 4-5. 
nieuprawniony do głosowania $z$ racji wieku) powinien interesować się wyborami, aby wyrobić w sobie dojrzałość obywatelska ${ }^{53}$.

Warto zaznaczyć, że w „Zwierciadle” wskazywano, że Polska dopiero „zmierza w kierunku demokracji”, a o układzie sił w sejmie nie będą decydować obywatele (jak w senacie), lecz polityczny przydział mandatów. Dostrzegano też rozbieżności i brak równowagi przy zgłaszaniu kandydatów ${ }^{54}$.

\section{Na nich warto głosować}

W pismach „Kobieta i Życia”, „Zwierciadło”, „Przyjaciółka” oraz „Filipinka” ukazywano specyfikę kampanii wyborczej. Redakcja „Zwierciadła"55 już pod koniec lutego 1989 r. informowała, że Liga Kobiet Polskich w wojewódzkich oddziałach przygotowuje się do kampanii wyborczej do Sejmu X kadencji. Anonsowano, że na listach pojawią się zarówno członkinie organizacji, jak i kobiety niezrzeszone ${ }^{56}$. W „Filipince” relacjonowano spotkanie $z$ ministrem Wilczkiem ${ }^{57}$. Na łamach „Przyjaciółki” informowano o rozpoczęciu kampanii wyborczej przez PZPR w czasie Krajowej Konferencji Delegatów PZPR, która odbyła się w dniach 4-5 maja. Zwrócono uwagę na tempo zmian w partii, ale też zbieżność poglądów redakcji na temat problemów społecznych. Konkludowano: „Partia w kampanię wyborczą wchodzi jako organizacja prężna, dynamiczna, zjednoczona wokół jasno sformułowanego programu. Przedstawiając swój program zwraca się zarazem do swoich członków, sympatyków, do wszystkich Polaków $z$ apelem o jego poparcie"s8.

W „Przyjaciółce” pojawił się reportaż ze spotkań wyborczych przedstawicieli władzy ${ }^{59}$. Redakcja zauważyła, że „kandydaci prowadzili taką kampanię wyborcza, jakiej w Polsce jeszcze nie było. Prezentowali siebie i swoje programy w ulotkach, na mityngach, na spotkaniach $z$ wy-

\footnotetext{
53 Hanna Jaworska, „Od Redaktora”, Fil, nr 11, 21.05.1989, 3.

54 Od strony rządowej nie wymagano dostarczenia podpisów obywateli pod listami, krajowe organizacje społeczne miały przedstawić 3 tys. podpisów $z$ różnych okręgów, a inicjatywy obywatelskie po 3 tys. podpisów z każdego okręgu; Elżbieta Wierzbicka, „Przedwyborcza ściagawka", $Z w$, nr 19, 11.05.1989, 4-5.

55 Pismo zostało zainicjowane przez Lige Kobiet Polskich.

56 Krystyna Stachowicz, „Miejsce Ligi”, $Z w, \mathrm{nr} 8,23.02 .1989,7$.

57 Grażyna Grzegorska, „Mister Minister”, Fil, nr 10, 7.05.1989, 5.

58 Ewa Łuszczuk, „Wszystko, co służy Polsce”, Prz, nr 20, 18.05.1989, 4.

59 Elżbieta Banasiak, „Hyde Park po warszawsku”, Prz, nr 21, 25.05.1989, 5.
} 
borcami - w najróżniejszych formach. Przedstawiani byli w prasie, radiu i telewizji” ${ }^{60}$. W „Zwierciadle” zamieszczano wywiady z politykami, choćby $z$ premierem Mieczysławem Rakowskim na temat stworzenia w rzadzie klimatu do rozwiąania problemów kobiet oraz dopuszczenia ich do decydowania politycznego ${ }^{61}$.

Należy wskazać, że przed wyborami kontraktowymi redakcje wskazanych pism prezentowały wykazy kandydatów, na których warto zagłosować. Redakcja „Kobiety i Życia” przeprowadziła sondę w środowisku intelektualistek i intelektualistów, w której wyniku zgromadzono informację o potencjalnych kandydatkach (m.in. o opinię zapytano: Irenę Głuszyńska z $z$ Wydziału Prawa UJ, pisarza Lesława Bartelskiego, reporterkę radiową Monikę Olejnik, adwokata i przewodniczącego Komisji Młodych Naczelnej Rady Adwokackiej Ryszarda Kalisza, prof. Zofię Kuratowska - lekarza, uczestniczkę podstolika ds. służby zdrowia, reprezentująca stronę opozycyjno-solidarnościowa) ${ }^{62}$, a 17 maja w rubryce "One nie zawioda" zaprezentowano opinie o kobietach, które sprawdziłyby się u władzy. Tygodnik przedstawił także własną „dziesiątkę”: Zofię Als-Iwańska, Małgorzatę Niepokulczycka, Barbarę Hoff, Barbarę Sass, doc. Renatę Siemińska, doc. Danutę Graniewska, Irenę Szczygielska, Alinę Tepli, dr Danutę Waniek i redaktor naczelna „Kobiety i Życia” Annę Szymańską-Kwiatkowska ${ }^{63} . Z$ wymienionych kandydatek na liście wyborczej znalazły się: Alina Tepli, Anna Szymańska-Kwiatkowska, Zofia Als-Iwańska, Małgorzata Niepokulczycka. Ich sylwetki prezentowano też w kolejnym numerze tygodnika wraz $z$ apelem: „Głosujcie na kobiety! One nie zawioda!!”. Najwięcej miejsca poświęcono redaktor naczelnej pisma, zaprezentowano jej transparent oraz ulotkę wyborczą ${ }^{64}$.

Również redakcje „Zwierciadła” i „Przyjaciółki” postulowały o poparcie w wyborach kobiet. 18 maja 1989 r. w „Zwierciadle”, a 1 czerwca w „Przyjaciółce” pojawiły się apele: „Głosuj na kobiety”. Przedstawiono stanowisko Komisji Porozumiewawczej Środowisk Kobiecych ds. Wyborów (z 25 kwietnia 1989 r.), gdzie wskazano, że kobiety stanowią połowę

\footnotetext{
60 „Wybierzmy najlepszych”, Prz, nr 22, 1.06.1989, 5.

61 „Nasze oczekiwania”, $Z w, \mathrm{nr} 12,23.03 .1989,5$.

62 „One nie zawioda”, KiŻ, nr 20, 17.05.1989, 4-5, 7, 12.

63 „Nasza dziesiątka zdaniem "Kobiety i Życia”- One nie zawioda!”, Ki்̇, nr 20, 17.05.1989, 13-15.

64 „One nie zawioda!!, KiŻ, nr 22, 31.05.1989, 2-3; Danuta Bierzańska, Olga Oswald, „Gorączka demokracji”, Kï̇, nr 22, 31.05.1989, 4.
} 
narodu, sa wykształcone, kompetentne, gospodarne i oszczędne, mają tzw. doświadczenie życiowe. Za istotne dla rozwoju państwa uznano wpływ kobiet przede wszystkim na politykę ekonomiczna i socjalną ${ }^{65}$.

Na łamach „Zwierciadła” prezentowano wywiady z kobietami, które zdecydowały się kandydować do sejmu. Szczególną uwagę poświęcono członkiniom Ligi Kobiet Polskich: Elżbiecie Lęcznarowicz - przewodniczącej Zarządu Głównego LKP, Elżbiecie Gacek - wiceprzewodniczącej ZG LKP, Zofii Kędzior - przewodniczącej Komisji ds. Gospodarstwa Domowego przy LKP, Alinie Tepli - członkini Zarządu LKP ${ }^{66}$.

W tygodniku „Przyjaciółka” promowano i udzielono poparcia dla kandydatów (Czesławy Górskiej, Andrzeja Bilika, Waldemara Zmaczyńskiego), którzy zgadzali się z sugestiami periodyku. Redakcja następująco argumentowała swoje stanowisko: „odpowiedzieli na apel redakcji i zobowiazali do realizacji postulatów"67. Popierano też: Elżbietę Lęcznarowicz, Marię Łopatkową, Małgorzatę Niepokulczycka, Alinę Tepli68, Annę Szymańska-Kwiatkowską ${ }^{69}$, Elżbietę Zając, Annę Gocławską ${ }^{70}$, Aleksandra Kwaśniewskiego, Stanisława Kwiatkowskiego, Leszka Millera, Dariusza Przywieczerskiego ${ }^{71}$.

W „Filipince” ubolewano, że organizacje młodzieżowe nie wystawiły zbyt wielu kobiet w wyborach i parlament nie będzie odzwierciedlał składu społeczeństwa. Niedoreprezentowani będą młodzież i kobiety. Wskazano, że najmłodsza kandydatka ma 27 lat. Opowiedziano się za oddaniem głosu na jedna $z$ dziewięciu proponowanych przez redakcję kobiet $^{72}$, dołączając ich biogramy.

65 „Komisja Porozumiewawcza Środowisk Kobiecych ds. Wyborów. Głosuj na kobiety!”, $Z w$, nr 20, 18.05.1989, 5; „Komisja Porozumiewawcza Środowisk Kobiecych ds. Wyborów. Głosuj na kobiety!”, Zw, nr 21, 25.05.1989, 2-3; „Komisja Porozumiewawcza Środowisk Kobiecych ds. Wyborów. Głosuj na nas!”, Prz, nr 22, 1.06.1989, 5.

66 Bożena Stolarska, „Głosuj na kobiety”, Zw, nr 21, 25.05.1989, 2-3.

67 Maria Zybert, „Popieramy: Czesławę Górska, Andrzeja Bilika, Waldemara Zmaczyńskiego", Prz, nr 21, 25.05.1989, 4.

68 „Popieramy: Elżbieta Lęcznarowicz, Maria Łopatkowa, Małgorzata Niepokulczycka, Alina Tepli", Prz, nr 22, 1.06.1989, 2-3.

69 „Popieramy: Anna Szymańska-Kwiatkowska, rozmawiała Wiesława Piątek”, Prz, nr 22, 1.06.1989, 4.

70 „Wybierzmy najlepszych”, Prz, nr 22, 1.06.1989, 5.

71 „Popieramy: Aleksandra Kwaśniewskiego, Stanisława Kwiatkowskiego, Leszka Millera, Dariusza Przywieczerskiego”, Prz, nr 22, 1.06.1989, 6.

72 Zaprezentowano biogramy: Barbary Jaskólskiej, Doroty Becker, Ewy Wichrowskiej, Teresy Dusiło, Małgorzaty Wysmyk, Anety Partyckiej, Elżbiety Iwony Nowickiej, Haliny 
Można zauważyć, że redakcje włączyły się w kampanię wyborcza. W pismach pojawiły się reportaże ze spotkań wyborczych, artykuły publicystyczne i ankiety na temat potencjalnych kandydatek i kandydatów. Następnie prezentowano biogramy osób, na które warto zagłosować, publikowano ich dłuższe sylwetki, zapraszano do wywiadów. Tygodniki promowały akcje „Głosuj na kobiety”. W pismach „Kobieta i Życie”, „Przyjaciółka”, „Zwierciadło” zgodnie popierano: Alinę Tepli, Annę Szymańska-Kwiatkowska, Małgorzatę Niepokulczycka, pojawiały się też inne kandydatki, a w „Przyjaciółce” poparto również mężczyzn. Znamienne było, że poparcia redakcji „Kobiety i Życia” nie uzyskała przewodniczaca LKP Elżbieta Lęcznarowicz.

\section{Powyborcze refleksje}

W tygodniku „Kobieta i Życie” $\mathrm{z}$ rozgoryczeniem pisano o wynikach wyborów w kontekście niewielkiej liczby mandatów uzyskanych przez kobiety. Zofia Als-Iwańska stwierdziła: „Stara to prawda niestety, że musimy być przynajmniej dwa razy lepsze od mężczyzn, aby im dorównać”73. Małgorzata Niepokulczycka wskazała:

w kampanii przedwyborczej przekonywano również, że my - kobiety nie musimy zajmować się polityka. Możemy spokojnie siedzieć w domu (czytaj: stać w kolejkach) ponieważ znajdą się obrońcy naszych praw ${ }^{74}$.

Alina Tepli podkreślała, że celowo umieszczono ją w drugiej turze wyborów w takim okręgu, aby nie udało się jej uzyskać mandatu. Za istotne uznała wypracowanie przez kobiety pozycji adekwatnej do ich liczebności w państwie, takiej, z którą będą się liczyły wszystkie siły polityczne, „nie będzie się nas wpisywać na listy do ozdoby ...”75. W cyklu „Bariery awansu" zwrócono uwagę, że państwo polskie jest uboższe niż społeczeństwo, gdyż państwem rządzą mężczyźni, gospodarstwem domowym natomiast kobiety. Zauważono, że główną bariera awansu kobiet jest system gospodarczy wymagający reform. Zdaniem redakcji do ich opracowania i realizacji odpowiednio przygotowane sa kobiety, które

Jarosz, Marii Popławskiej, zob. szerzej: Hanna Jaworska, „Od Redaktora”, Fil, nr 12, 4.06.1989, 3.

73 Zofia Als-Iwańska, „Nie obiecywałam złotych gór”, KiŻ, nr 26, 28.06.1989, 2.

74 Małgorzata Niepokulczycka, „We wstecznym lusterku”, Ibidem.

75 Alina Tepli, „Nie czuję się przegrana”, KiŻ, Ibidem. 
w organizacji gospodarstwa domowego posługują się zasadą racjonalnego działania, a więc minimalizuja nakłady, aby osiagnać założony cel ... lub maksymalizację efektu przy założonych nakładach ${ }^{76}$.

$Z$ promowanych przez redakcję nazwisk mandat otrzymała redaktor naczelna „Kobiety i Życia” Anna Szymańska-Kwiatkowska, która zadeklarowała walkę o realne równouprawnienie płci ${ }^{77}$.

Na niereprezentatywność kobiet w parlamencie zwrócono również uwage w „Zwierciadle”. Ustalono, że w Sejmie X kadencji będzie zasiadać mniejsza liczba posłanek (61) niż w Sejmie IX kadencji (94). Wskazano też, że najwięcej kobiet znalazło się na listach wyborczych Komitetu Obywatelskiego „Solidarność” (127 na 211 wszystkich kandydatek), z ramienia Polskiej Zjednoczonej Partii Robotniczej kandydowało 69 kobiet, ze Zjednoczonego Stronnictwa Ludowego - 12, natomiast ze Stronnictwa Demokratycznego $-3^{78}$. W celu przybliżenia sylwetek posłanek w lipcu zainicjowano rubrykę „Twoje posłanki”.

Można zauważyć, że w „Przyjaciółce”, „Filipince”, „Magazynie Rodzinnym” podsumowania wyborów zwiąane były z zadaniami, które powinien wypełnić nowy rząd. Wskazano też na koszty, które należy ponieść, aby sytuacja gospodarcza Polski uległa poprawie ${ }^{79}$. Z kolei w „Zwierciadle” oraz „Kobiecie i Życie” dostrzegano mniejsza liczbę mandatów poselskich uzyskanych przez kobiety, co wpłynęło na zaangażowanie pism w promocję posłanek i senatorek.

\section{Zakończenie}

Na podstawie badań prasy dla kobiet w Polsce w okresie od lutego do lipca 1989 r. należy wskazać, że rynek prasowy podzielony był na prasę stricte poradnikowa (w zakresie mody, stylu, urody, wykrojów) oraz opiniotwórczą (głównie reprezentowana przez tygodniki „Przyjaciółka”, „Kobieta i Życie”, „Zwierciadło”), w której pojawiły się też tematy społecz-

\footnotetext{
${ }^{76}$ K.G.M, „Bariery awansu: «Kury» biurowe i naukowe”, KiŻ, nr 27, 5.07.1989, 2.

77 Anna Szymańska-Kwiatkowska, „Czas nagli”, Ki்̇, nr 26, 28.06.1989, 2.

78 Barbara Adamczewska, „Kobiety w Sejmie i Senacie”, Zw, nr 27, 6.07.1989, 2.

79 „Zmiany wymaga nie tylko Fundusz Alimentacyjny. Ruta Pragier rozmawia $z$ Anną Kędzierska, pełnomocnikiem rządu ds. kobiet”, Prz, nr 25, 22.06.1989, 4; „To my, możemy wygrać!”, Prz, nr 26, 29.06.1989, 4; Elżbieta Banasiak, „Czas na działanie”, Prz, nr 28, 13.07.1989, 4; Hanna Jaworska, „Od Redaktora”, Fil, nr 15, 16.07.1989, 3; „Od Redaktora”, Magazyn Rodzinny, nr 183, lipiec 1989, 45.
} 
ne i polityczne. W tej drugiej obecne były dyferencjacje zwiazane $z$ adresatami poszczególnych pism. Pod katem dominujacej w nich tematyki oceniano przygotowanie do przemian ustrojowych, przebieg kampanii wyborczej i efekt wyborów kontraktowych.

Dostrzec można zależność pomiędzy oceną obrad Okragłego Stołu i wyborów czerwcowych. Pozytywna opinia redakcji na temat porozumień koalicji rządowej z opozycją solidarnościową stanowiła asumpt do aprobowania wyników wyborów. Na obraz wyborów kontraktowych w prasie dla kobiet wpływ miały też sprawy, które zdominowały kampanię wyborcza, głównie projekt ustawy o prawnej ochronie dziecka poczętego, jak również kwestia równości szans kobiet i mężczyzn. Zauważalne było porozumienie redakcji w zakresie wspierania w wyborach kobiet. Redakcje włączały się w kampanię wyborcza, zachęcając do poparcia konkretnych kandydatek i kandydatów. W związku $z$ tym na łamach pism publikowano ich sylwetki, reportaże ze spotkań wyborczych, przeprowadzano $z$ nimi wywiady. Zainteresowanie redakcji wzbudziły również niespotykane dotąd narzędzia kampanii wyborczej.

Obraz wyborów kontraktowych na łamach polskiej prasy dla kobiet miał trzy wymiary: historyczny - zwracano uwage na znaczenie przemian dla przyszłości Polski, edukacyjny - apelowano o udział w wyborach oraz odpowiedzialny i świadomy wybór kandydatów, perspektywiczny - dostrzegano w nich szanse na aktywizację kobiet w polityce.

Należy też podkreślić, że optymizm był neutralizowany stwierdzeniami o konieczności poniesienia kosztów transformacji ustrojowej, której pozytywne efekty będa odczuwane za kilka lat. Zdawano sobie sprawę również $\mathrm{z}$ faktu, że wybory kontraktowe do sejmu nie miały w pełni charakteru demokratycznego, lecz stanowiły wynik kompromisu.

\section{Bibliografia}

\section{Źródła:}

Adamczewska, Barbara. „Kobiety w Sejmie i Senacie”, Zwierciadło $[Z w]$, nr 27, 6.07.1989.

Als-Iwańska, Zofia. „Nie obiecywałam złotych gór”, KiŻ, nr 26, 28.06.1989. AMO. „Punktujemy”, Filipinka [Fil], nr 10, 7.05.1989.

Banasiak, Elżbieta. „Czas na działanie”, Przyjaciółka [Prz], nr 28, 13.07.1989. 
Banasiak, Elżbieta. „Hyde Park po warszawsku”, Prz, nr 21, 25.05.1989.

Banasiak, Elżbieta. „Propozycje dla rządu”, Prz, nr 1, 5.01.1989.

Banasiak, Elżbieta. „Wiosna w polskim parlamencie”, Prz, nr 13, 30.03.1989.

Bierzańska, Danuta, Oswald, Olga. „Goraczka demokracji”, KiŻ, nr 22, 31.05.1989.

„Blisko życia zwykłych ludzi. "Kobieta i Życie» rozmawia z przewodnicząca Ligi Kobiet Polskich Elżbietą Lęcznarowicz", rozm. Alicja Bińska, KiŻ, nr 23, 7.06.1989.

„Budować od dołu”, wywiad Wiesławy Lipińskiej z prof. Arturem Bodnarem, Zw, nr 6, 9.02.1989.

„Chcemy o tym decydować”, Zw, nr 16, 20.04.1989.

„Chcemy o tym decydować”, Zw, nr 21, 25.05.1989.

„Chcemy o tym decydować”, Zw, nr 22, 1.06.1989.

„Chcemy o tym decydować”, Zw, nr 24, 15.06.1989.

Czaj, Joanna. „Wywiad z Wandą Chrzanowska: Przebudzenie?”, Ki்̇, nr 22, 31.05.1989.

„[Czterdzieści] 40 lat minęło", oprac. Ewa Tałandziewicz-Glebko, Świat Mody (lato 1989), nr 160, 1989.

Fra. „Jak głosujemy?”, Ki்̇, nr 22, 31.05.1989.

Frankowska, Anna. „Protokół rozbieżności”, KiŻ, nr 24, 14.06.1989.

Grzegorska, Grażyna. „Mister Minister”, Fil, nr 10, 7.05.1989.

Gutek, Alina. „Daleko od stołu”, Zw, nr 14, 6.04.1989.

„Jacy powinni być posłowie”, wypowiedzi wysłuchała Elżbieta Banasiak, Prz, nr 20, 18.05.1989.

„Jak wybieramy?”, Prz, nr 22, 1.06.1989.

Jaworska, Hanna. „Od Redaktora”, Fil, nr 5, 26.02.1989.

Jaworska, Hanna. „Od Redaktora”, Fil, nr 9, 23.04.1989.

Jaworska, Hanna. „Od Redaktora”, Fil, nr 10, 7.05.1989.

Jaworska, Hanna. „Od Redaktora”, Fil, nr 11, 21.05.1989.

Jaworska, Hanna. „Od Redaktora”, Fil, nr 12, 4.06.1989.

Jaworska, Hanna. „Od Redaktora”, Fil, nr 15, 16.07.1989.

„Jeśli nie my, to kto?”, Ki்̇, nr 20, 17.05.1989.

K.G.M. „Bariery awansu: "Kury» biurowe i naukowe”, Ki்̇, nr 27, 5.07.1989. K.K-R. „Bolesna sprawa”, Prz, nr 24, 15.06.1989.

„Komisja Porozumiewawcza Środowisk Kobiecych ds. Wyborów, Głosuj na kobiety", Zw, nr 20, 18.05.1989. 
„Komisja Porozumiewawcza Środowisk Kobiecych ds. Wyborów, Głosuj na kobiety!", $Z w, \mathrm{nr}$ 21, 25.05.1989.

„Komisja Porozumiewawcza Środowisk Kobiecych ds. Wyborów, Głosuj na nas!", Prz, nr 22, 1.06.1989.

Kopczewska, Renata. „Prawo do decyzji”, Magazyn Rodzinny, nr 182, czerwiec 1989.

Kurczab-Redlich, Krystyna. „Sprawa przerywania ciąży: Ostatnia furtka”, Prz, nr 18, 4.05.1989.

Lipińska, Wiesława. „Nowe budownictwo”, $Z w$, nr 19, 11.05.1989.

Łuszczuk, Ewa. „Wszystko, co służy Polsce”, Prz, nr 20, 18.05.1989.

Młynarczyk, Joanna. „Oczy Pollyanny”, Fil, nr 12, 4.06.1989.

Młynarczyk, Joanna. „Pochodowe? Alternatywne”, Fil, nr 10, 7.05.1989.

"Nasza "Dziesiątka" Zdaniem "Kobiety i Życia" - "One nie zawiodą»!", KiŻ, nr 20, 17.05.1989.

„Nasze oczekiwania”, $Z w$, nr 12, 23.03.1989.

„Nie ma racji bezwarunkowych”, Magazyn Rodzinny, nr 183, lipiec 1989.

Niepokulczycka, Małgorzata. „We wstecznym lusterku”, KiŻ, nr 26, 28.06.1989.

„O nas bez nas”, oprac. Krystyna Kaszuba, KiŻ, nr 13, 29.03.1989.

„O nas bez nas”, oprac. Krystyna Kaszuba, KiŻ, nr 45, 22.11.1989.

„O nas bez nas (2)”, oprac. Krystyna Kaszuba, KIŻ, nr 14, 5.06.1989.

OBOP. „Informacja z badań przedwyborczych”, PF 2/89, V 1989.

OBOP. „Informacja $z$ badań przedwyborczych (trzy tygodnie przed wyborami)", PF 3/89, 19.05.1989.

OBOP. „Komunikat $z$ badań: Inauguracja obrad Okragłego Stołu w opinii mieszkańców Warszawy”, nr 4/506, 7.02.1989.

OBOP. „Komunikat z badań: Nastroje społeczne w maju 1989 r.”, nr 20/520, V 1989.

OBOP. „Komunikat $z$ badań: Opinie mieszkańców Warszawy o obradach Okragłego Stołu", nr 14/516, 7.04.1989.

Obserwator. „Reflektory na Polskę, Prz, nr 7, 16.02.1989.

"Ochrona zdrowia - sprawa publiczna”, wywiad Barbary Skrzypińskiej z Zofią Kuratowska, $Z w$, nr 18, 4.05.1989.

"Od Redaktora”, Magazyn Rodzinny, nr 183, lipiec 1989.

„One nie zawioda!”, KiŻ, nr 20, 17.05.1989.

„One nie zawioda!", Ki்̇, nr 22, 31.05.1989. 
„Ostrożny optymizm”, rozmowa Elżbiety Wierzbickiej z doc. dr. hab. Stanisławem Gebethnerem, $Z w$, nr 20, 18.05.1989.

Piątek, Wiesława. „By wybierać dobrze”, Prz, nr 18, 4.05.1989.

Piątek, Wiesława. „Na dobry poczatek”, Prz, nr 15, 13.04.1989.

Piątek, Wiesława. „Nie zmarnujmy szansy”, Prz, nr 7, 16.02.1989.

„Pisane kobieca ręką. Listy, które w lutym i marcu br. nadeszły do uczestników Okragłego Stołu czytała i do druku podała Natalia Iwaszkiewicz", KiŻ, nr 15, 12.04.1989.

„Popieramy: Aleksandra Kwaśniewskiego, Stanisława Kwiatkowskiego, Leszka Millera, Dariusza Przywieczerskiego", Prz, nr 22, 1.06.1989.

„Popieramy: Anna Szymańska-Kwiatkowska”, rozmawiała Wiesława Piątek, Prz, nr 22, 1.06.1989.

„Popieramy: Elżbieta Lęcznarowicz, Maria Łopatkowa, Małgorzata Niepokulczycka, Alina Tepli”, Prz, nr 22, 1.06.1989.

Redakcja. „Przed wyborami do Sejmu i Senatu: przeczytaj - zastanów się przedstaw swój pogląd", Prz, nr 19, 11.05.1989.

Redakcja. „To my możemy wygrać!”, Prz, nr 19, 11.05.1989.

Stachowicz, Krystyna. „Czekamy na partnera”, Zw, nr 17, 27.04.1989.

Stachowicz, Krystyna. „Jedność w różnorodności”, Zw, nr 17, 27.04.1989.

Stachowicz, Krystyna. „Miejsce Ligi”, Zw, nr 8, 23.02.1989.

„Stanowisko Ligi Kobiet Polskich w sprawie dopuszczalności przerywania ciąży", $Z w$, nr 18, 4.05.1989.

„Stanowisko Ligi Kobiet Polskich w sprawie dopuszczalności przerywania ciąży w związku $\mathrm{z}$ projektem poselskim ustawy o prawnej ochronie dziecka poczętego", KiŻ, nr 20, 17.05.1989.

„Stare wątpliwości”, rozmowa Elżbiety Wierzbickiej z prof. Jerzym Ciemieniewskim, ekspertem strony opozycyjno-solidarnościowej przy Okragłym Stole, $Z w$, nr 20, 18.05.1989.

Stolarska, Bożena. „Głosuj na kobiety”, $Z w$, nr 21, 25.05.1989.

„Stwórzmy zdrową szkołę", rozmowa Aliny Gutek z prof. Henrykiem Samsonowiczem, przewodniczącym komisji oświaty i nauki w Komitecie Obywatelskim przy Lechu Wałęsie, $Z w$, nr 19, 11.05.1989.

Szymańska-Kwiatkowska, Anna. „Czas nagli”, KiŻ, nr 26, 28.06.1989.

Tepli, Alina. „Nie czuję się przegrana”, Ki்̇, nr 26, 28.06.1989.

„To musisz wiedzieć, by mieć własne zdanie”, Prz, nr 27, 6.07.1989.

„To my, możemy wygrać!”, Prz, nr 26, 29.06.1989. 
Wierzbicka, Elżbieta. „Przedwyborcza ściagawka”, Zw, nr 19, 11.05.1989.

„Wybierzmy najlepszych”, Prz, nr 22, 1.06.1989.

„Za i przeciw...”, $Z w$, nr 20, 18.05.1989.

„Za i przeciw...”, $Z w$, nr 19, 11.05.1989.

„Za i przeciw ustawie”, $Z w, \mathrm{nr} 18,4.05 .1989$.

„Zabieg 2”, KiŻ, nr 14, 5.06.1989.

„Zmiany wymaga nie tylko Fundusz Alimentacyjny”, Ruta Pragier rozmawia $z$ Anną Kędzierską, pełnomocnikiem rządu ds. kobiet, Prz, nr 25, 22.06.1989.

Zubczewska, Zofia. „Maż uważa, czyli antykoncepcja po polsku”, Ki̇̇, nr 17, 26.04.1989.

Zwolińska-Kańtoch, Bożena. „Od Redaktora”, Magazyn Rodzinny, nr 182, czerwiec 1989.

Zybert, Maria. „Popieramy: Czesławę Górska, Andrzeja Bilika, Waldemara Zmaczyńskiego", Prz, nr 21, 25.05.1989.

„Źle strzeżona brama”, Ki்̇, nr 15, 5.04.1989.

\section{Opracowania:}

Dudek, Antoni. Reglamentowana rewolucja, (Kraków : Wydawnictwo Znak, 2014). ISBN 978-83-240-3027-9.

Friszke, Andrzej. Rok 1989: polska droga do wolności (Warszawa : Wydawnictwo Sejmowe, 2009). ISBN 978-83-7059-930-0.

„Kalendarium wyborcze”, w: Polska Wybory '89, układ i wyb. Roman Kałuża (Warszawa : Wydawnictwo Andrzej Bonarski, 1989), 24-171. ISBN 8385089004.

Kowal, Paweł. Koniec systemu władzy. Polityka ekipy gen. Wojciecha Jaruzelskiego w latach 1986-1989, (Warszawa : Narodowe Centrum Kultury, 2015). ISBN 978-83-7982-154-9.

Lewartowska, Zofia. „Prasa kobieca i rodzinna”, Zeszyty Prasoznawcze, nr 4, 1975, 65-70. ISSN 0555-0025.

Małkiewicz, Andrzej. Wybory czerwcowe 1989, (Warszawa : ISP PAN, 1994). ISBN 83-85479-63-5.

Paczkowski, Andrzej. Od sfałszowanego zwycięstwa do prawdziwej klęski. Szkice do portretu PRL, (Kraków : Wydawnictwo Literackie, 1999). ISBN 83-08-02912-4. 
Pisarek, Walery. Wstęp do nauki o komunikowaniu, (Warszawa : Wydawnictwo Akademickie i Profesjonalne, 2008). ISBN 978-83-60501-14-6.

Sokół, Zofia. „Redaktorzy naczelni czasopism kobiecych w Polsce w latach 1944-1982 (portret zbiorowy)", Kwartalnik Historii Prasy Polskiej, t. 30, nr 1, 1991, 87-98. ISSN 0137-2998.

Sokół, Zofia. „Transformacja czasopism kobiecych w Polsce (1989-1997)”, Rocznik Historii Prasy Polskiej, t. 1, z. 1-2, 1998, 193-201. ISSN 15091074

Trembicka, Krystyna. Okragły stół $w$ Polsce: studium o porozumieniu politycznym, (Lublin : Wydawnictwo UMCS, 2003). ISBN 83-227-2165-X. 